\title{
Crossing the divide
}

\section{Coverage from ACRL's 10th National Conference, Part 1}

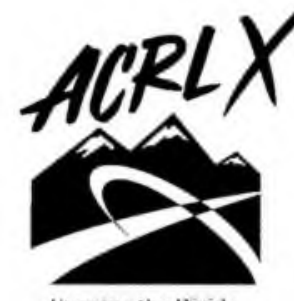

Crossing the Divide Denver $\rightarrow$ March 15-18, 2001

10 countries-were able to choose from more than 250 programs and preconferences on topics such as distance education, assessment, scholarly communication, and information literacy. Programs and workshops on information literacy were particularly "hot," with attendees crowding the meeting rooms.

The conference featured engaging speakers such as Michael Hawley (Dreyfoos assistant professor of Media Technology, MIT Media Lab), who stimulated the capacity crowd with his discussion, "The Technology Revolution." Additional keynote and featured speakers included Patricia Limerick (chair, Center of the American West), Claire Gaudiani (president, Connecticut College), and Clifford Lynch (executive director, Coalition for Networked Information), whose "informal conversation" with conference attendees led to thought-pro- voking dialogue on technology, intellectual property, and fair use.

"It was a very exciting and stimulating conference. A record-breaking number of attendees networked, exchanged ideas, and participated in sessions that will help them address issues on their campus and allow them to provide more efficient services to constituents both on and off campus," stated Betsy Wilson, ACRL president.

The conference also offered numerous opportunities for attendees to meet with corporate sponsors. More than 180 companies displayed their state-ofthe-art products and services in the exhibit hall.

CERL News is pleased to offer the following summaries of selected conference programs, and thanks the many volunteers who provided these reports. Part two will appear in the June issue of CERL News.

\section{The technology revolution}

Michael Hawley's opening address, "The Technology Revolution," focused on technological innovations and the role they can play in improving society. After reminding the audience about his ACRL presentation in 1989, he marveled at the advances since "the late bronze age of the computer world." 


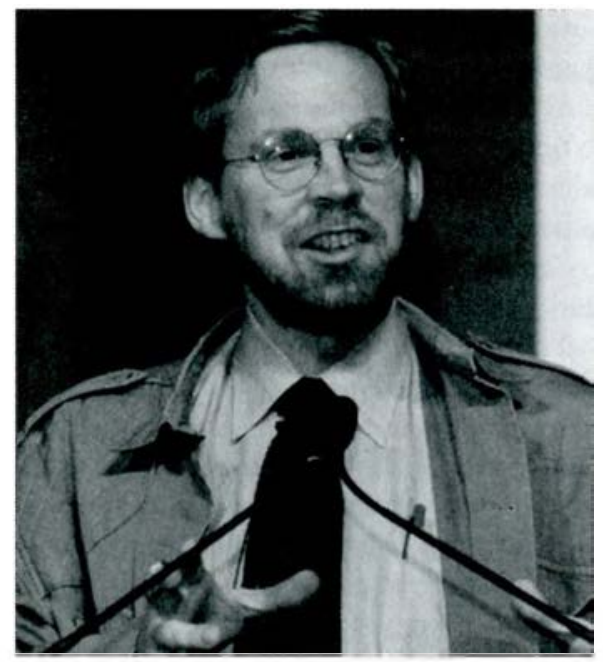

Michael Hawley, Dreyfoos assistant professor of Media Technology at MIT Media Lab, encouraged attendees to play with toys.

To illustrate his point, he explained how merging the rotary steam engine with the printing press resulted in speedier printing, which led to the creation of cheap newsprint, which in turn contributed to a more literate population. In the same vein, he commented that joining computers and the telephone system has given us the Internet, and it is still unclear what impact 5,10 , or 15 years will bring.

Toys, he said, are profound, "You're never more creative than when you're playing." $\mathrm{He}$ described light-emitting diodes and explained how they could be used to indicate the ideal water temperature for showers. He talked about coffee makers that distinguish between espresso and cappuccino cups and about refrigerator magnets with built-in video capabilities. He showed laser cuttings in vegetables and nuts, posed the question, "What if ingredients could talk to you?" and explained the ramifications of "counter intelligence" research (for the kitchen). He went on to describe jars that play salsa, an electronic nose, fanny packs that display vital medical statistics, pills that measure internal body temperatures, bathroom scales that chart weight fluctuations, and a $\$ 500,000$ pin that glows with each heartbeat.

Hawley continued by describing the impact of providing computers to an orphanage in Cambodia. When asked about the potential for technology pollution during the questionand-answer session, he expressed confidence that the public will demand quality and pro- vided the example of how a piano, once considered technology, is now used as furniture. To the question of what to do about children relying too much on media, he pointed out that while the television cannot respond to questions, the Internet is interactive. Finally, to the issue of technologically advanced toys stifling imagination, he replied that investing oneself in playing with any toy can have positive effects.-Allison King, University of Central Florida-Brevard Campus, aking@mail.ucf.edu

\section{Western voices}

Patricia Limerick, chair of the Center of the American West at the University of Colorado, Boulder, is arguably the most prominent practicing historian of the U.S. western experience; this day she also demonstrated that she is surely among our wittiest scholars. In remarks leavened with self-deprecation, highlighted by frequent references to her struggles with technophobia, she speculated in her presentation, "Western Voices," that librarians may be suffering more ambivalence about the electronic information revolution than the professional literature represents.

After declaring "The world has changed and I cannot keep up," Limerick hopefully announced that she is becoming less a dinosaur

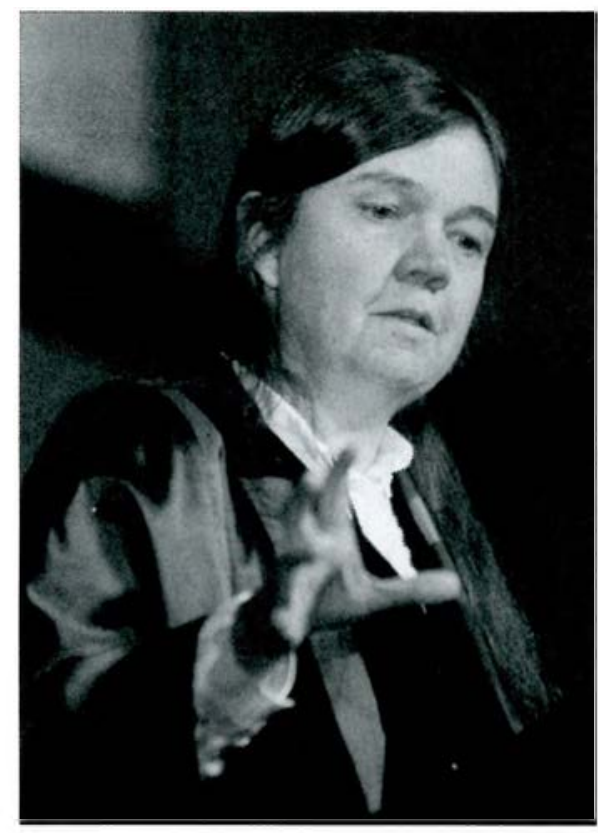

Patricia Limerick, chair of the Center of the American West at the University of Colorado, Boulder, talked about the West as an evolving myth. 


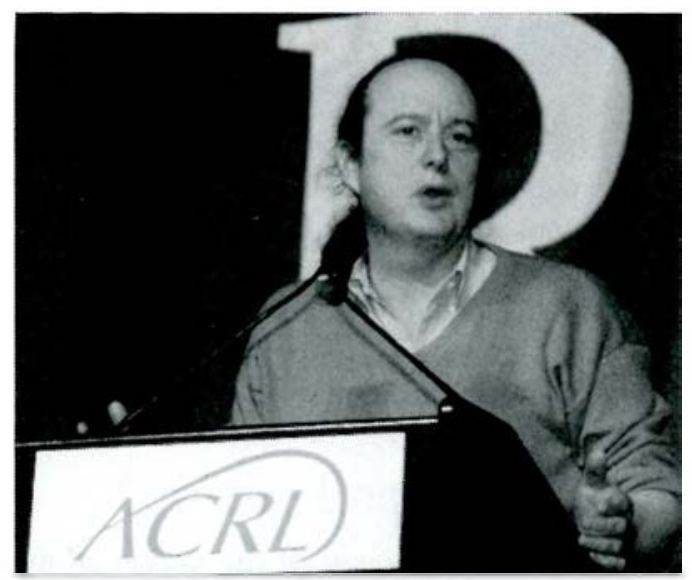

Clifford Lynch, CNI, challenged the audience to become experts in instructional technology.

and more a condor who "flies around." Limerick depicted a West-American's fastest growing region-like librarianship under stress from rapid development; but in the West, nostalgia for past better days has been a century-and-ahalf constant.

While shooting insights and jokes through seemingly every one of her rapidly delivered sentences, Limerick's theme of the West as an evolving myth emerged. She expounded at always-illuminating length on the forthcoming Handbook. for New Westerners, a project that has taken her and geographer Bill Travis to numerous communities throughout the West, soliciting ideas from residents about what is essential in the region. Their efforts have predictably uncovered many competing notions about the authentic West, including the phenomenon of individuals often holding passionate, contradictory, and simultaneous feelings on a particular subject, such as the sovereignty of property owners alongside the need for increased environmental protectionism.

The question-and-answer period offered no letdown from the main talk. Limerick touched upon comparative American West and international history, the sensitive mission of public history endeavors, and the possible role of genes in Left Coast urbanization. All who attended were stimulated and reminded of the intellectual context in which libraries vitally serve.-Scolt H. Silverman, Bryn Mawr College Libraries, ssilverm@brynmawredu

\section{Emerging technology and policy trends}

In "Emerging Technology and Policy Trends,"
Clifford Lynch, executive director of the Coalition for Networked Information (CNI), had a conversation with the audience, responding to questions about the impact of technology, fair use in a digital environment, and the futures of libraries and librarians.

On the issue of fair use, Lynch characterized it as a defense against lawsuits. He said that libraries currently have a well-established standard for print, but digital content cannot be judged the same way. He added that percentages cannot be applied to images and using the whole image cannot be defined as fair use.

Lynch challenged the audience to collaborate and become experts in instructional technology. He suggested that libraries should become the laboratories for building the digital infrastructure by tapping their expertise with the residential experience and by taking advantage of technologies provided by their research responsibilities. He said that in a very powerful and tangible way, technology is allowing us to do things we have never done before. He said that it gives us wild possibilities, but also adds stress and is sometimes overwhelming, but if we can manage this doubleedged sword, we will have interesting systems of great value.

Lynch said that the recent failure of many dot.coms has led to the rampant sale of customer database information and raised many privacy questions. He added that vendors have added privacy language to site licenses, but there is very little policing of violations.

Lynch stated the impacts of technology included cheaper storage, Broadband is developing, and computational cycles are growing. He felt that home adoption of Broadband is the next big change, followed by better access to film, video, and images.

The decision to make the Napster Web site copyright compliant led Lynch to predict filtering will cause unintended consequences as thwarted technology inventors will build stronger, more secure systems. "It's an 'arms race' with those building racing against those trying to shut them down." Lynch predicted that the library will be used less for storage and more for teaching, collaboration, and social interaction-Diane Kachmar, Florida Atlantic University,kachmar@fau.edu

\section{Digital reference}

Do yout students know the Ask Jeeves Web 
address better than they know your library's URL? Based on the steady decline in reference desk questions in most academic libraries, we know our users aren't always thinking of us first when they have a research question. Academic library users have discovered Internet "Ask an Expert" services that offer the immediate gratification of an answer to any question.

How can academic libraries position themselves to be the information and instruction service of choice in the 21st century? R. David Lankes (Information Institute of Syracuse) discussed in his presentation, "Digital Reference: The Future of Academic Reference," the necessity of developing digital reference services to serve the demands and expectations of our users. He said that we must realize that our users value anytime/anyplace reference service. Where academic libraries can trounce our commercial competitors is in the area of expertise and human intermediation.

Lankes envisions a national digital reference system made up of libraries, expent reference systems such as Ask Jeeves, industry help desks, and federal agencies. These groups would cooperate to provide seamless access to answers and experts, regardless of the user's time zone or physical location. Additionally, academic libraries have a resource other reference services do not- the expertise of the faculty and librarians. Lankes proposes that academic libraries develop a "network of expertise," where we value library and faculty staff and expertise as much as we treasure our digital collections.-Iulia K. Nims, Eastern Michigan University,jnims@online.emich.edu

\section{Indochinese students' behavior in using academic libraries}

In "Services for New American Users: Indochinese Students' Behavior in Using Academic Libraries," Cathy Anne Lu (University of California, Berkeley) reported on a study investigating the use of library resources by a group of Indochinese students. She selected her university and San Jose State University to administer a questionnaire survey and interviews because of their large Asian population.

The purpose of her study was to determine whether these students made effective use of academic libraries, to assess the usefulness of the library services, and to identify ways to improve and implement those ser-
vices. From data collected. Lu reported that it appeared that although many of these students were at the library, they rarely used its resources. She added that they did not show familiarity with the library's offerings but were willing to seek assistance from staff when confronted with a library-related problem.

Lu emphasized that cultural differences prevented them from acknowledging difficulty with the English language and that denial of this problem made bibliographic instruction sessions less effective. Lu said that in most cases, with English not spoken at home, students tended to select science-related fields where written papers were not generally expected. Consequently, they did not need to develop the library skills expected in some disciplines.

Having identified the needs of this population, Lu offered several recommendations:

A librarian needs to be sensitive to the cultural needs of its patrons and engage them in the effective use of a library's resources; various outreach programs and library workshops should be developed for this population.

Lu hopes her study will alert administrators and other academic library personnel to the often overlooked needs of a portion of their population, and prompt more effective ways to help these patrons better use their

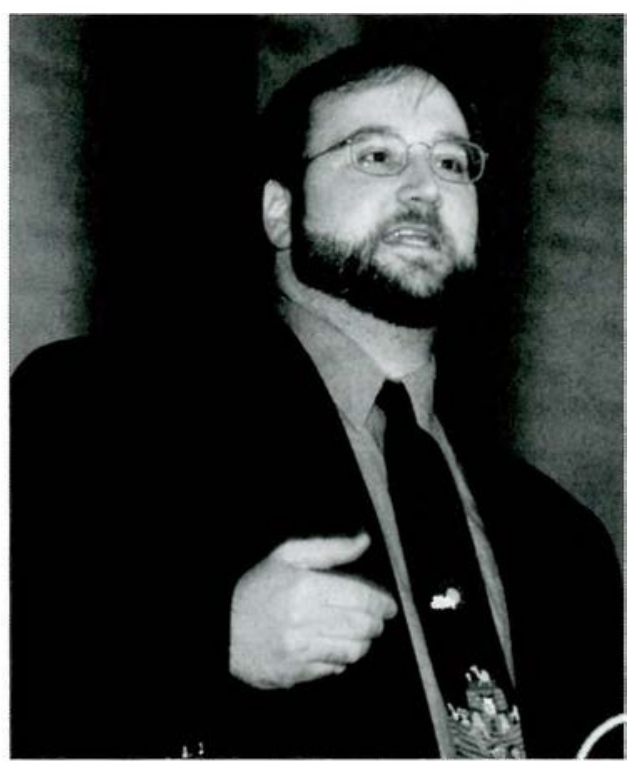

R. David Lankes of the Information Institute of Syracuse emphasized the importance of anytime/anyplace reference service. 


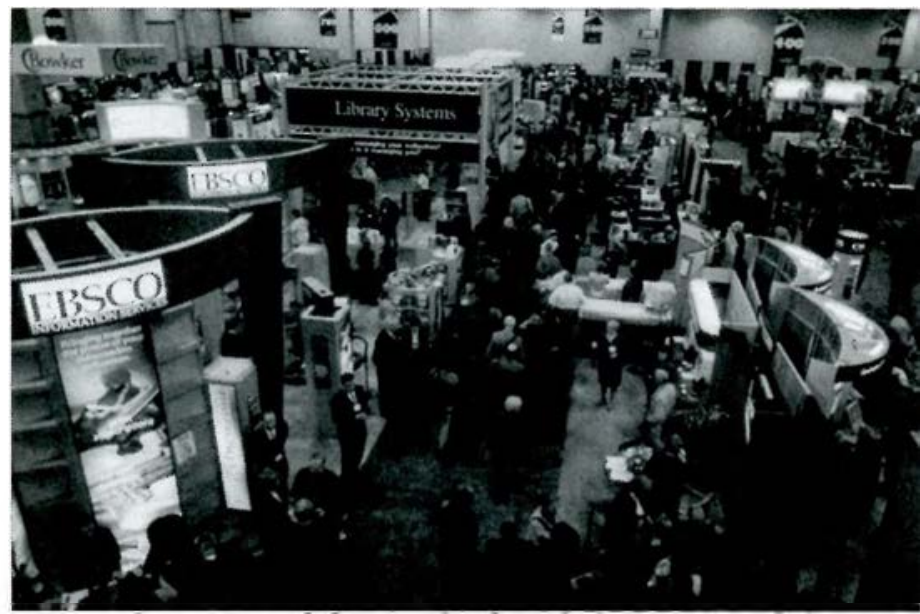

More than 180 exhibitors displayed their state-of-the-art products and services in the exhibit hall.

library's resources. - Teresa L. Abaid, Florida Atlantic University, abaid@fau.edu

\section{Assessment of student learning}

"Assessment of student learning: it is not a matter of if, but a question of how." With this comment Debra Gilchrist (Pierce College) concluded this session, "Assessment of Student Learning," but how did it begin?

The invited speaker Kenneth Smith (University of Arizona) discussed his ARL white paper, "New Roles and Responsibilities for the University Library: Advancing Student Learning Through Outcomes Assessment" (http://www.arl.org/stats/newmeas/heo.html). He emphasized that in the past, assessment of student learning focused on content, but in the current knowledge economy there is a shift towards competencies. He said this relates directly to the expertise of library professionals, who teach students information literacy skills. However, Smith noted, conversation throughout the university is the most important factor, because all components of the learning community-including classroom faculty, library faculty, and administrators-

\section{Miss a program?}

Audiocassette tapes of most conference programs are available for purchase. Check onsite at http://www ala.org/acrl/denver. html for details.

Selected sessions will also be available for on-demand Web viewing. Sessions will be announced on the ACRL Web site this month. contribute to student learning outcomes.

Gilchrist shared Smith's excitement, and urged librarians to view their role in developing assessment tools as "an opportunity, rather than as one more thing to do." Like Smith, she emphasized the importance of experimentation. Guiding the initiatives at her library was the recognition that students were "not simply learning how to use the library, but instead were learning information literacy skills and the research process."

Bob Mohrbacher (Pierce College) explained how he and the library faculty collaborated. He recognized that students could find a book, but lacked the skills to find literary criticism in periodicals or databases. With the library faculty, he devised assignments that required students to find, evaluate, and incorporate information into their research projects. As a result of these initiatives, he said that library and English faculty have seen a wider range of sources and a better use of these sources in student assignments.-Penny Bealle, AdelphiUniversity, bealle@adelphiedu

\section{Problems with new state UCITA laws}

In "Problems Presented by New State Uniform Information Laws (UCITA): Respecting the Use of Electronic Resources," Vicki Gregory (University of South Florida) reviewed the UCITA legislation, a set of proposed state laws regulating software licensing and electronic resources that has already passed in Maryland (effective October 1, 2000) and Virginia (effective July 1, 2001). She added, it has been, or will soon be, introduced in Arizona, Florida, Georgia, Illinois, Maine, and Texas. She said that vendors could list your license agreement final arbitrator as a state court where UCITA is in effect.

Gregory explained that the implication of UCITA for libraries is that it will replace copyright law, undercut fair use, and undermine the preservation and lending of information products. She said that UCITA binds companies to licensing terms in software acquired by their employees without prior authorization. Gregory said that licenses are not trans- 
ferable if a company changes names and software vendors can prohibit public criticism of their product and can shut down their software remotely, without court approval, merely on suspicion of possible licensing violations (a "self-help" clause).

Gregory outlined for librarians these responses to UCITA: know what UCITA is and which version is being considered in your state; inform your legislators; align with other interest groups who would also be

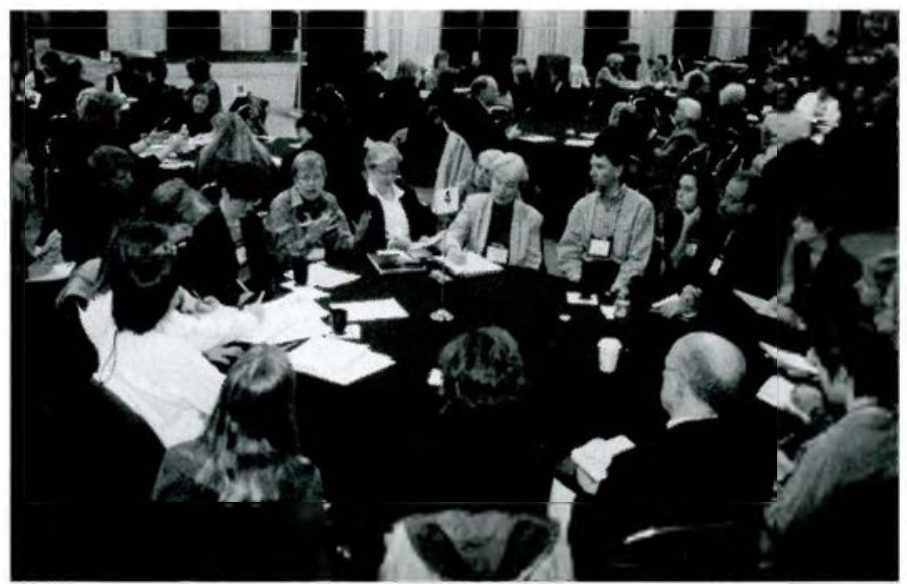

Roundtable discussions gave attendees the opportunity to chat informally about common issues. adversely affected (insurance, publishing, small business, etc.); and consider compromises, such as removal of anti-criticism and self-help provisions, and addition of library exemptions.

Gregory urged the attendees to educate staff and users, maintain a file of licenses (including shrink-wrap and click-through agreements), and make sure they are clear about all licensing terms of agreement if the state passes UCITA,.-Kitti Canepi, Florida Gulf Coast University, kcanepi@fgcu.edu

\section{A president's view}

At the closing session, in "A President's View," Clair Gaudiani, president of Connecticut College, urged stepping back and looking at the

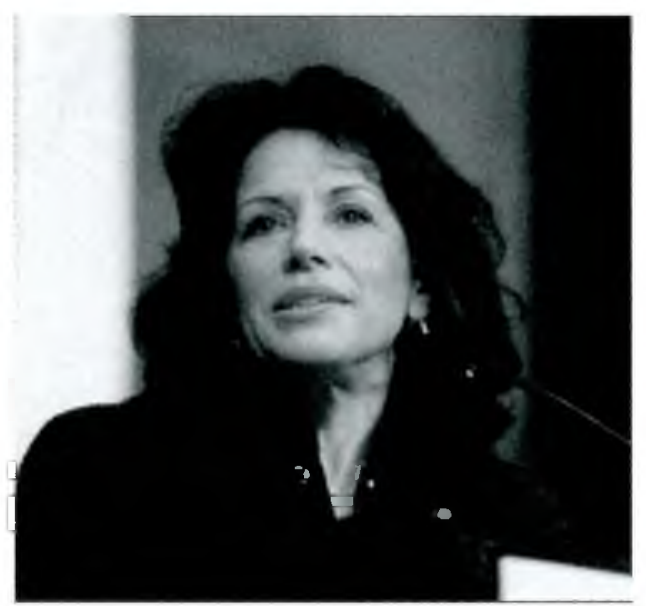

Claire Gaudiani, president of Connecticut College, urged civic commitment and engagement saying, "Higher education works to enable human beings to reach higher levels of development." big picture, asking fundamental questions that relate what we're doing with who we're trying to be in a global environment. She quoted author Robert Lane, who documented selfreported happiness levels, and concluded that even with highest levels of wealth production people are not happier. He asked, "How can we not be happier?" Gaudiani urged civic engagement, civic commitment, said that knowledge like wealth in a democracy tends to congregate, to concentrate. She said as we move forward we must speak of the importance of values to decide how we will live with more wealth, more knowledge.

She said that John Winthrop in 1630 wrote of his expectation that in this new land people would share with those who had less to create a stronger nation. A discussion of values that are important to our work opportunities is essential.

Gaudiani claimed that the three values of curiosity, generosity, and integrity apply especially to libraries and librarians. "Higher education works to enable human beings to reach higher levels of development." This should begin in libraries. The need to create an environment for civic engagement is as important as any other issue in libraries." She continued, "We must integrate the doing it better than ever with being at the values level. We are as close as any generation has ever been to kinds of values our founding fathers set before us with flaws they knew were there."

"This is our work even while struggling with all other issues."-Vinginia Bailey, Abilene Cbristian University, baileyv@acu.edu 
As part of a botany assignment,

Maria was attempting to study how genetic variation affects S. pseudocapiscum.

The first step was to visit the library and learn how genes affect plant traits.

She found some answers in an eBook.

$(1)$

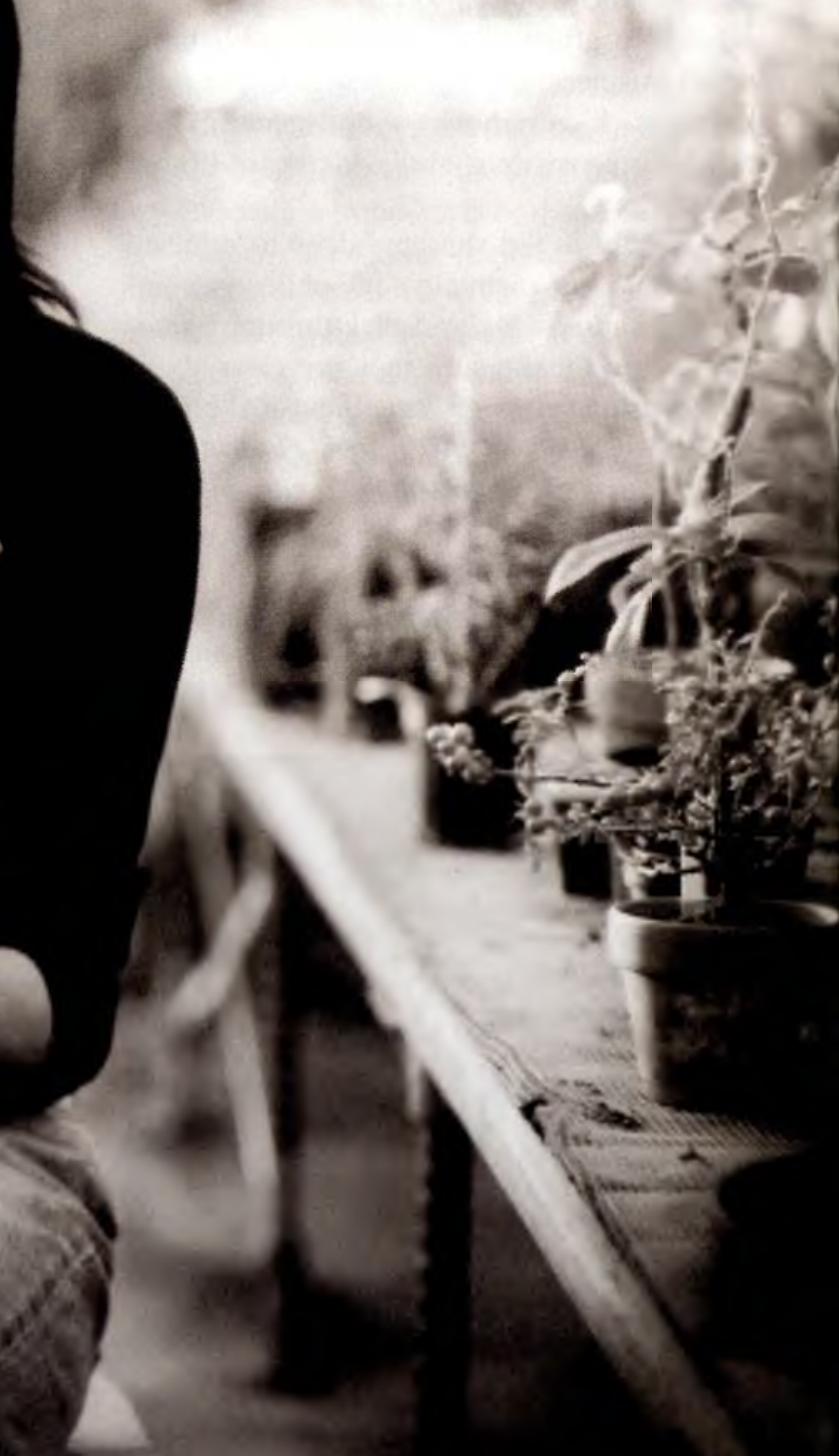


To us, it's not just how students use eBooks, it's how students use libraries, as well. To that end, we develop collections of eBooks to help librarians provide increased access to valued, reliable knowledge in electronic form. Our eBooks, by design, fit well into libraries, with efficient search features, OPAC integration, and content from top publishers such as Oxford University Press. To learn more, visit academic.netLibrary.com or call 800-413-4557.

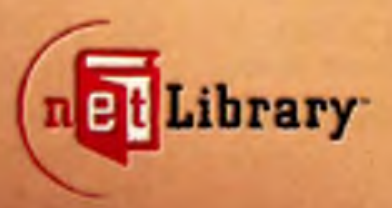

